\title{
CD40, a Novel Inducer of Purinergic Signaling: Implications to the Pathogenesis of Experimental Diabetic Retinopathy
}

\author{
Carlos S. Subauste ${ }^{1,2}$ \\ 1 Division of Infectious Diseases and HIV Medicine, Department of Medicine, Case Western Reserve \\ University, Cleveland, OH 44106, USA; carlos.subauste@case.edu; Tel.: +1-216-368-2785 \\ 2 Department of Pathology, Case Western Reserve University, Cleveland, $\mathrm{OH}$ 44106, USA \\ Academic Editor: Tetsuya Sugiyama \\ Received: 18 July 2017; Accepted: 9 August 2017; Published: 12 August 2017
}

\begin{abstract}
Diabetic retinopathy is a leading complication of diabetes. Death of capillary cells with resulting capillary degeneration is a central feature of this disease. Chronic low-grade inflammation has been linked to the development of retinal capillary degeneration in diabetes. CD40 is an upstream inducer of a broad range of inflammatory responses in the diabetic retina and is required for death of retinal capillary cells. Recent studies uncovered CD40 as a novel inducer of purinergic signaling and identified the CD40-ATP-P2X $X_{7}$ pathway as having a key role in the induction of inflammation in the diabetic retina and programmed cell death of retinal endothelial cells.
\end{abstract}

Keywords: diabetes; retina; Müller cells; endothelial cells; inflammation; cell death

\section{Introduction}

Diabetes is one of the most common chronic diseases in the world. The prevalence of diabetes worldwide in 2014 increased to $8.5 \%$ in adults over 18 years of age leading to the estimation that there are 422 million patients with diabetes in the world [1]. Microangiopathy is a major cause of morbidity and mortality in diabetics and the retina is one of the main tissues affected by diabetic microvascular disease. The overall prevalence of diabetic retinopathy (DR) is 35\% among individuals with diabetes [2]. Moreover, DR is the leading cause of vision loss among individuals from 20 to 74 years of age in the United States [3].

Retinal vascular pathology is a key cause of clinically significant loss of vision in diabetics. Early vascular lesions of DR include the death of retinal endothelial cells and pericytes [4]. This leads to the transformation of capillaries into tubes of basement membrane devoid of cells (capillary degeneration). Degenerate retinal capillaries lack blood flow [5] and thus contribute to the development of retinal ischemia and subsequent neovascularization in advanced diabetic retinopathy. Neovascularization and macular edema are leading causes of vision loss in DR.

Various mechanisms appear to link chronic hyperglycemia to the development of microangiopathy. These include oxidative stress, increased polyol pathway flux, increased hexosamine pathway flux, activation of protein kinase $\mathrm{C}$ and increased formation of advanced glycation-end products [6]. Chronic low grade inflammation also plays an important role in the pathogenesis of DR [7]. ICAM-1 is upregulated in retinal endothelial cells in diabetic retinas from humans and rodents, and ICAM-1 promotes an increase in the number of leukocytes adherent to vessel walls (leukostasis) in diabetic rats [8,9]. Blockade of ICAM-1 diminishes capillary degeneration in diabetic mice [10]. Retinal levels of inducible nitric oxide synthase (NOS2) are increased of patients with DR and in diabetic rodents [11,12]. Moreover, diabetic NOS2 ${ }^{-/}$mice are protected from retinal leukostasis and capillary degeneration $[13,14]$. The vitreous fluid in patients with proliferative DR [15] and retinas of diabetic 
rodents [16] exhibit increased expression of the chemokine (C-C motif) ligand 2 (CCL2, also known as monocyte chemoattractant protein 1 or MCP-1). CCL2 recruits leukocytes including monocytes and dendritic cells to sites of inflammation. The correlation between CCL2 protein levels in the vitreous with the clinical stage of diabetic proliferative retinopathy [17] suggests a pathogenic role for this chemokine.

\section{CD40 is Required for Development of Experimental DR}

Increasing evidence indicates that CD40 is a key upstream regulator of various inflammatory responses in the diabetic retina and a central mediator of the development of experimental DR [18-21]. CD40 is a TNF receptor superfamily member expressed on various hematopoietic and non-hematopoietic cells [22-24]. CD154 (CD40 ligand) is expressed on activated T cells and platelets, and can also be present in plasma as a soluble protein [22,23]. In addition to retinal microglia/macrophages, non-hematopoietic cells including retinal endothelial cells (REC), Müller cells and retinal ganglion neurons have constitutive low-level expression of CD40 [25].

The CD40-CD154 pathway is activated in diabetes: CD40 expression is increased in Müller cells, REC and microglia/macrophages in diabetic mice [20], and blood levels of CD154 are increased in diabetic mice and patients with microangiopathy [21,26-28]. Moreover, serum CD154 from diabetics induces pro-inflammatory responses in endothelial cells and monocytes [28]. Studies in diabetic CD40-/- mice revealed that CD40 is central to ICAM-1 upregulation in REC, leukostasis, upregulation of TNF- $\alpha$, IL-1 $\beta$ and NOS2 retinal mRNA levels, retinal protein nitration and increased CCL2 mRNA in the retina [19-21]. In addition, diabetic $\mathrm{CD}_{4} 0^{-/-}$mice do not develop capillary degeneration indicating that CD40 is critical for early experimental DR [20,21]. In vitro studies also support the importance of CD40 as a key mediator of inflammatory responses in retinal cells. CD40 ligation causes upregulation of ICAM-1, CCL2, NOS2 and PGE 2 in Müller cells and/or REC [19]. CD40 stimulation in macrophages/microglia increases TNF- $\alpha$ and IL-1 $\beta$ secretion and upregulates NOS2 [29-31].

\section{CD40 is a Novel Inducer of Purinergic Signaling: CD40 Induces ATP Release by Müller Cells Triggering P2X $\mathrm{X}_{7}$-Driven TNF- $\alpha / \mathrm{IL}-1 \beta$ Production by Macrophages/Microglia}

Myeloid cells are central mediators of inflammation. However, studies using bone marrow transplants in a mouse model of ischemia/reperfusion-induced retinopathy (a CD40-driven disease) revealed the importance of CD40 expressed on non-hematopoietic cells for the development of ischemic retinopathy. The induction of retinal inflammation with the resulting increase in ganglion neuron loss in this model requires expression of CD40 in non-hematopoietic cells but not in hematopoietic cells [32]. In addition, we recently uncovered a novel mechanism by which CD40 on non-hematopoietic cells (Müller cells) induces by-stander macrophages/microglia to express pro-inflammatory cytokines and promote development of experiment diabetic retinopathy [21,33].

Müller cells are the main macroglia in the retina. These cells become dysfunctional in diabetes and contribute to the development of experimental DR [34]. Transgenic mice on a CD40-/- background that exhibit rescue of CD40 restricted to Müller cells (Trg-CD40 mice) were generated to study the role of CD40 expressed in Müller in the pathogenesis of DR [21]. After becoming diabetic, these mice exhibit upregulation of TNF- $\alpha$, IL-1 $\beta$, ICAM-1, NOS2 and CCL2 in the retina and develop capillary degeneration (early experimental DR) [21]. Diabetic transgenic mice without rescue of CD40 (Trg-Ctr mice) do not upregulate these pro-inflammatory molecules and do not develop capillary degeneration [21]. Interestingly, in vitro studies revealed that while Müller cells secrete CCL2 in response to CD40 ligation, these cells do not produce TNF- $\alpha$ and IL- $1 \beta$ in response to this stimulation $[19,21]$. These findings raised the possibility that CD40 stimulation in Müller cells recruits other retinal cells to upregulate TNF- $\alpha$ and IL-1 $\beta$. Indeed, co-culture experiments of Müller cells and monocyte/macrophages showed that CD40 ligation causes release of extracellular ATP by in Müller cells that in turn triggers TNF- $\alpha$ and IL-1 $\beta$ secretion by monocytes/macrophages that is mediated by the purinergic receptor $\mathrm{P} 2 \mathrm{X}_{7}$ expressed on these myeloid cells [21]. Several lines of evidence support 
the in vivo relevance of the newly discovered CD40-ATP-P2X 7 pathway in experimental DR. Retinal microglia/macrophages are the cells that upregulate TNF- $\alpha$ protein levels both in diabetic Trg-CD40 mice and in diabetic wild-type (WT) animals [21,35]. Diabetic Trg-CD40 mice treated with the P2X inhibitor BBG and diabetic P2X ${ }_{7}^{-/-}$mice do not upregulate TNF- $\alpha$ and IL- $1 \beta$, as well as NOS2 and ICAM-1, molecules induced by TNF- $\alpha /$ IL-1 $\beta$ [21]. Further support of the relevance of CD40-ATP-P2X pathway in experimental DR comes from the demonstration that both diabetic Trg-CD40 mice and WT mice upregulate $\mathrm{P}_{2} \mathrm{X}_{7}$ protein levels in retinal microglia/macrophages [21]. This finding is significant because $\mathrm{P} 2 \mathrm{X}_{7}$ upregulation is a key feature of $\mathrm{P} 2 \mathrm{X}_{7}$-driven diseases and increased $\mathrm{P} 2 \mathrm{X}_{7}$ expression in microglia is sufficient to stimulate pro-inflammatory cytokine expression [36]. Taken together, these results suggest that the CD40-ATP-P2X 7 pathway is a central mediator of upregulation of TNF- $\alpha$, IL-1 $\beta$, NOS2 and ICAM-1 in the diabetic retina (Figure 1).

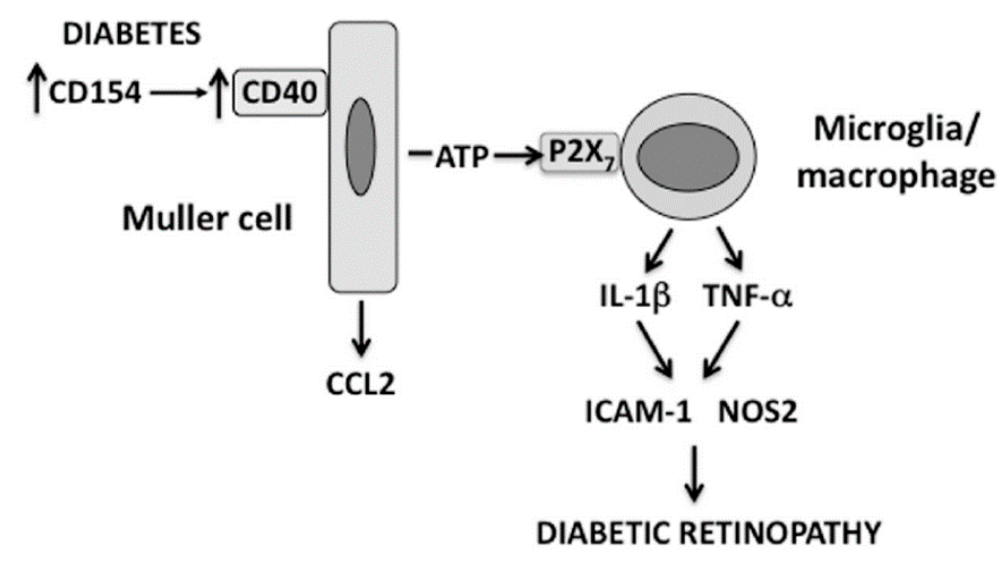

Figure 1. The CD40-ATP-P2 $X_{7}$ pathway links cellular responses in Müller cells with the induction of inflammatory responses in bystander microglia/macrophages in DR. Blood levels of CD154 and expression of CD40 on Müller cells are increased in diabetes. CD40 ligation in Müller cells causes CCL2 upregulation and secretion of extracellular ATP. In turn, ATP binds P2 $\mathrm{X}_{7}$ expressed in microglia/macrophages leading to upregulation of TNF- $\alpha$ and IL-1 $\beta$ as well as ICAM-1 and NOS2, pro-inflammatory molecules that can be induced by these inflammatory cytokines.

Increase in cytoplasmic $\mathrm{Ca}^{2+}$ is a mechanism that can lead to release of extracellular ATP. Recent evidence supports that CD40 stimulation causes release of extracellular ATP through activation of phospholipase $\mathrm{C} \gamma 1$ (PLC $\gamma 1$ ), a molecule that causes $\mathrm{Ca}^{2+}$ flux from the endoplasmic reticulum into the cytoplasm increasing cytoplasmic $\mathrm{Ca}^{2+}$ concentrations [21]. CD40 ligation in Müller cells causes rapid tyrosine 783 phosphorylation of PLC $\gamma 1$, a marker of PLC $\gamma 1$ activation [21]. CD40 stimulation is reported to increase cytoplasmic $\mathrm{Ca}^{2+}$ in $\mathrm{B}$ cells and smooth muscle cells $[37,38]$. Moreover, incubation with the calcium chelator BAPTA AM or with the PLC inhibitor U73122 prevents the ability of CD40 ligation to cause release of ATP [21]. These findings support the conclusion that PLC $\gamma 1$ acts as a molecular link between CD40 and activation of purinergic signaling.

\section{The CD40-ATP-P2X 7 Pathway Mediates Programmed Cell Death (PCD) of Retinal Endothelial Cells}

Death of REC results in the development of degenerate capillaries, an event believed to cause retinal ischemia. Various mechanisms appear to contribute to the development of capillary degeneration. These include increased oxidative and nitrosative stress [12,13,39-41] as well as expression of inflammatory molecules (TNF- $\alpha$, IL-1, ICAM-1) [42-45]. CD40 is upregulated in REC of diabetic mice and the presence of CD40 is required for development of capillary degeneration. However, CD40 ligation on endothelial cells promotes their survival rather than death. $\mathrm{P}_{2} \mathrm{X}_{7}$ can induce cell death by apoptosis or necrosis [46]. Indeed, the CD40-ATP-P2X 7 pathway explains how 
CD40 can lead to PCD of REC. Müller cells closely associate with REC and, as explained above, secrete ATP in response to CD40 ligation. While REC are relatively resistant to PCD when incubated with extracellular ATP, CD40 ligation in these cells causes $\mathrm{P}_{2} \mathrm{X}_{7}$ upregulation making them susceptible to ATP-dependent PCD [18]. This mechanism is likely to occur in vivo since P2 $\mathrm{X}_{7}$ is upregulated in REC from diabetic $\mathrm{B} 6$ but not $\mathrm{CD} 40^{-/-}$mice, and diabetic $\mathrm{CD} 40^{-/-}$and $\mathrm{P} 2 \mathrm{X}^{-/-}$mice exhibit reduced PCD of REC [18]. Altogether, the CD40-ATP-P2X 7 pathway appears to be an important driver of PCD of REC in diabetes (Figure 2). Given that primary human pericytes also express CD40 (J-A Portillo and C.S. Subauste, unpublished observations), it is possible that the CD40-ATP-P2X 7 pathway may also mediate PCD of retinal pericytes in diabetes.

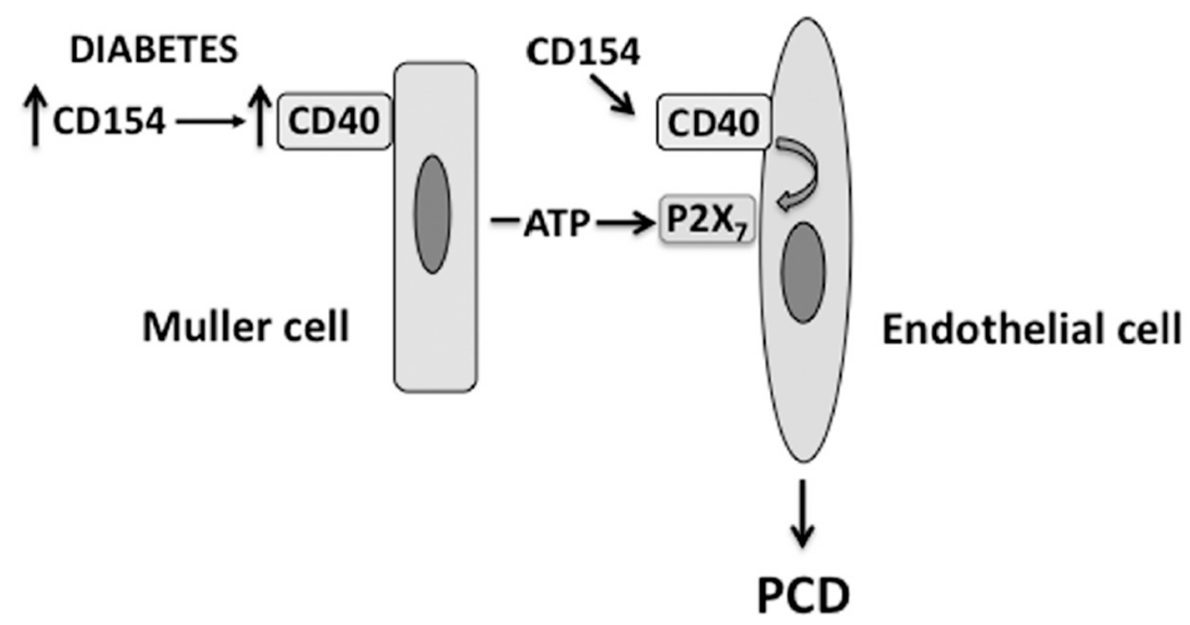

Figure 2. The CD40-ATP-P2 $X_{7}$ pathway links cellular responses in Müller cells with programmed cell death (PCD) of bystander REC in DR. Blood levels of CD154 and expression of CD40 on Müller cells are increased in diabetes. CD40 ligation in Müller cells causes secretion of extracellular ATP. At the level of REC, CD40 upregulates $\mathrm{P}_{2} \mathrm{X}_{7}$ expression, making REC susceptible to $\mathrm{P}_{2} \mathrm{X}_{7}$-induced programmed cell death.

Further support of the importance of $\mathrm{P}_{2} \mathrm{X}_{7}$ in diabetic microangiopathy comes from the demonstration that induction of diabetes is accompanied by increased susceptibility of retinal microvessels to P2 $X_{7}$-mediated death $[47,48]$. Functional studies suggest that the number of P2X receptors is not significantly increased in retinal microvessels of diabetic animals [47]. Similarly, fibroblasts exposed to high glucose and fibroblasts isolated from diabetics exhibit increased susceptibility to $\mathrm{P} 2 \mathrm{X}_{7}$-mediated cell death through a mechanism that does not require upregulation of $\mathrm{P}^{2} \mathrm{X}_{7}$ expression [49,50]. Taken together, these studies suggest that CD40-mediated $\mathrm{P} 2 \mathrm{X}_{7}$ upregulation and hyperglycemia-induced changes in intrinsic receptor properties may contribute to the increased death of retinal capillary cells in diabetes.

The studies discussed herein uncovered CD40 as a key mediator of DR. It remains to be determined how CD40 is upregulated in diabetes and how CD154 gains access to the retina. The discovery of the CD40-ATP-P2X 7 pathway provided the first definitive demonstration that an inflammatory disorder can develop when CD40 is expressed exclusively in a non-hematopoietic cell. This finding is likely to have therapeutic implications. CD40 is a recognized target for the treatment of various diseases with an inflammatory component. Signaling pathways downstream of CD40 have different relative roles in the induction of inflammatory responses in hematopoietic vs. non-hematopoietic cells $[19,30]$. CD40-TNF Receptor Associated Factor 6 (TRAF6) is the signaling pathway by which CD40 induces inflammatory responses in myeloid cells [30,51], but is also central to the activation of various cell-mediated immune responses required for control of intracellular pathogens [30,31,51,52]. Thus, attempts to inhibit CD40 signaling active in myeloid cells have the risk of causing susceptibility to opportunistic infections. While CD40-TRAF6 signaling also promotes inflammatory responses in 
non-hematopoietic cells, blockade of CD40-TRAF2 signaling is sufficient to markedly impair these responses in non-hematopoietic cells including Müller cells [19,30,53]. Moreover, the CD40-TRAF2 pathway does not play a significant role in the induction cell-mediated immune responses [30,31,51,52]. The demonstration that CD40 signaling in Müller cells activates inflammatory responses not only in Müller cells but also in bystander microglia/macrophages suggests that inhibitors of CD40-TRAF2 signaling may effectively inhibit inflammation at the level of both non-hematopoietic and myeloid cells in DR.

Acknowledgments: This work was supported by NIH Grant EY019250 (C.S.S) and grant 1-2009-204 from the Juvenile Diabetes Foundation International (C.S.S).

Conflicts of Interest: The author declares no conflict of interest.

\section{References}

1. World Health Organization Global Report on Diabetes; World Health Organization: Geneva, Switzerland, 2016.

2. Yau, J.W.; Rogers, S.L.; Kawasaki, R.; Lamoureux, E.L.; Kowalski, J.W.; Bek, T.; Chen, S.J.; Dekker, J.M.; Fletcher, A.; Grauslund, J.; et al. Global prevalence and major risk factors of diabetic retinopathy. Diabetes Care 2012, 35, 556-564. [CrossRef] [PubMed]

3. Kempen, J.H.; O’Colmain, B.J.; Leske, M.C.; Haffner, S.M.; Klein, R.; Moss, S.E.; Taylor, H.R.; Hamman, R.F. The prevalence of diabetic retinopathy among adults in the United States. Arch. Ophthalmol. 2004, 122, 552-563. [PubMed]

4. Mizutani, M.; Kern, T.S.; Lorenzi, M. Accelerated death of retinal microvascular cells in human and experimental diabetic retinopathy. J. Clin. Invest. 1996, 97, 2883-2890. [CrossRef] [PubMed]

5. Kohner, E.M.; Henkind, P. Correlation of fluorescein angiogram and retinal digest in diabetic retinopathy. Am. J. Ophthalmol. 1970, 69, 403-414. [CrossRef]

6. Brownlee, M. Biochemistry and molecular cell biology of diabetic complications. Nature 2001, 414, 813-820. [CrossRef] [PubMed]

7. Tang, J.; Kern, T.S. Inflammation in diabetic retinopathy. Prog. Retin. Eye Res. 2011, 30, 343-358. [CrossRef] [PubMed]

8. McLeod, D.S.; Lefer, D.J.; Merges, C.; Lutty, G.A. Enhanced expression of intracellular adhesion molecule-1 and P-selectin in the diabetic human retina and choroid. Am. J. Pathol. 1995, 147, 642-653. [PubMed]

9. Miyamoto, K.; Khorsrof, S.; Bursell, S.E.; Rohan, R.; Murata, T.; Clermont, A.C.; Aiello, L.P.; Ogura, Y.; Adamis, A.P. Prevention of leukostasis and vascular leakage in streptozotocin-induced diabetic retinopathy via intercellular adhesion molecule-1 inhibition. Proc. Natl. Acad. Sci. USA 1999, 96, 10836-10841. [CrossRef] [PubMed]

10. Joussen, A.M.; Poulaki, V.; Le, M.L.; Koizumi, K.; Esser, C.; Janicki, H.; Schraermeyer, U.; Kociok, N.; Fauser, S.; Kirchhof, B.; et al. A central role for inflammation in the pathogenesis of diabetic retinopathy. FASEB J. 2004, 18, 1450-1452. [CrossRef] [PubMed]

11. El-Asrar, A.M.A.; Desmet, S.; Meersschaert, A.; Dralands, L.; Missotten, L.; Geboes, K. Expression of the inducible isoform of nitric oxide synthase in the retinas of huma subjects with diabetes mellitus. Am. J. Ophthalmol. 2001, 132, 551-556. [CrossRef]

12. Du, Y.; Smith, M.A.; Miller, C.M.; Kern, T.S. Diabetes-induced nitrative stress in the retina, and correction by aminoguanidine. J. Neurochem. 2002, 80, 771-779. [CrossRef] [PubMed]

13. Zheng, L.; Du, Y.; Miller, C.; Gubitosi-Klug, R.A.; Kern, T.S.; Ball, S.; Berkowitz, B.A. Critical role of inducible nitric oxide synthase in degeneration of retinal capillaries in mice with streptozotocin-induced diabetes. Diabetologia 2007, 50, 1987-1996. [CrossRef] [PubMed]

14. Leal, E.C.; Manivannan, A.; Hosoya, K.-I.; Terasaki, T.; Cunha-Vaz, J.; Ambrósio, A.F.; Forrester, J.V. Inducible nitric oxide synthase isoform is a key mediator of leukostasis and blood-retinal barrier breakdown in diabetic retinopathy. Investig. Ophthalmol. Vis. Sci. 2007, 48, 5257-5265. [CrossRef] [PubMed]

15. El-Asrar, A.M.A.; Van Damme, J.O.; Put, W.; Veckeneer, M.; Dralands, L.; Billiau, A.; Missotten, L. Monocyte chemotactic protein-1 in proliferative vitroretinal disorders. Am. J. Ophthalmol. 1997, 123, 599-606. [CrossRef]

16. Zhang, S.X.; Wang, J.J.; Gao, G.; Shao, C.; Mott, R.; Ma, J.X. Pigmented epithelium-derived factor (PEDF) is an endogenous antiinflammatory factor. FASEB J. 2006, 20, 323-325. [PubMed] 
17. Mitamura, Y.; Takeuchi, S.; Matsuda, A.; Tagawa, Y.; Mizue, Y.; Nishihira, J. Monocyte chemotactic protein-1 in the vitreous of patients with proliferative diabetic retinopathy. Ophthalmologica 2001, 215, 415-418. [CrossRef] [PubMed]

18. Portillo, J.-A.; Lopez Corcino, Y.; Dubyak, G.R.; Kern, T.S.; Matsuyama, S.; Subauste, C.S. Ligation of CD40 in human retinal Muller cells induces P2X7 receptor-dependent death of retinal endothelial cells. Investig. Ophthalmol. Vis. Sci. 2016, 57, 6278-6286. [CrossRef] [PubMed]

19. Portillo, J.-A.; Schwartz, I.; Zarini, S.; Bapputy, R.; Kern, T.S.; Gubitosi-Klug, R.A.; Murphy, R.C.; Subauste, M.C.; Subauste, C.S. Pro-inflammatory responses induced by CD40 in retinal endothelial and Muller cells are inhibited by blocking CD40-TRAF2,3 or CD40-TRAF6 signaling. Investig. Ophthalmol. Vis. Sci. 2014, 55, 8590-8597. [CrossRef] [PubMed]

20. Portillo, J.-A.C.; Greene, J.A.; Okenka, G.; Miao, Y.; Sheibani, N.; Kern, T.S.; Subauste, C.S. CD40 promotes the development of early diabetic retinopathy. Diabetologia 2014, 57, 2222-2231. [CrossRef] [PubMed]

21. Portillo, J.-A.C.; Lopez Corcino, Y.; Miao, Y.; Tang, J.; Sheibani, N.; Kern, T.S.; Dubyak, G.R.; Subauste, C.S. CD40 in retinal Muller cells induces P2X7-dependent cytokine expression in macrophages/microglia in diabetic mice and development of early experimental diabetic retinopathy in mice. Diabetes 2017, 66, 483-493. [CrossRef] [PubMed]

22. Grewal, I.S.; Flavell, R.A. CD40 and CD154 in cell-mediated immunity. Ann. Rev. Immunol. 1998, 16, 111-135. [CrossRef] [PubMed]

23. Van Kooten, C.; Banchereau, J. CD40-CD40 ligand. J. Leuk. Biol. 2000, 67, 2-17.

24. Andrade, R.M.; Wessendarp, M.; Gubbels, M.J.; Striepen, B.; Subauste, C.S. CD40 induces macrophage anti-Toxoplasma gondii activity by triggering autophagy-dependent fusion of pathogen-containing vacuoles and lysosomes. J. Clin. Invest. 2006, 116, 2366-2377. [CrossRef] [PubMed]

25. Portillo, J.-A.C.; Okenka, G.; Kern, T.S.; Subauste, C.S. Identification of primary retinal cells and ex vivo identification of pro-inflammatory molecules in retinal cells using flow cytometry. Mol. Vis. 2009, 15, 1383-1389. [PubMed]

26. Varo, N.; Vincent, D.; Libby, P.; Nuzzo, R.; Calle-Pascual, A.L.; Bernal, M.R.; Fernández-Cruz, A.; Veves, A.; Jarolim, P.; Varo, J.J.; et al. Elevated plasma levels of the atherogenic mediator soluble CD40 ligand in diabetic patients. A novel target of thiazolidinediones. Circulation 2003, 107, 2644-2649. [CrossRef] [PubMed]

27. Yngen, M.; Ostenson, C.-G.; Hu, H.M.; Li, N.; Hjemdahl, P.; Wallen, N.H. Enhanced P-selectin expression and increased soluble CD40 ligand in patients with type 1 diabetes mellitus and microangiopathy: Evidence for platelet hyperactivity and chronic inflammation. Diabetologia 2004, 47, 537-540. [CrossRef] [PubMed]

28. Cipollone, F.; Chiarelli, F.; Davi, G.; Ferri, C.; Desideri, G.; Fazia, M.; Iezzi, A.; Santilli, F.; Pini, B.; Cuccurullo, C.; et al. Enhanced soluble CD40 ligand contributes to endothelial cell dysfunction in vitro and monocyte activation in patients with diabetes mellitus: Effect of improved metabolic control. Diabetologia 2005, 48, 1216-1224. [CrossRef] [PubMed]

29. Kiener, P.A.; Moran-Davis, P.; Rankin, B.M.; Wahl, A.F.; Aruffo, A.; Hollenbaugh, D. Stimulation of CD40 with purified soluble gp39 induces proinflammatory responses in human monocytes. J. Immunol. 1995, 155, 4917-4925. [PubMed]

30. Portillo, J.-A.C.; Greene, J.A.; Schwartz, I.; Subauste, M.C.; Subauste, C.S. Blockade of CD40-TRAF2,3 or CD40-TRAF6 intercations is sufficient to impair pro-inflammatory responses in human aortic endothelial cells and human aortic smooth muscle cells. Immunology 2015, 144, 21-33. [CrossRef] [PubMed]

31. Portillo, J.-A.C.; Muniz-Feliciano, L.; Subauste, M.C.; Heinzel, F.P.; Subauste, C.S. CD40 and TNF-a synergize to induce nitric oxide synthase in macrophages. Immunology 2012, 135, 140-150. [CrossRef] [PubMed]

32. Subauste, C.; Portillo, J.A.; Zheng, L.; Okenka, G.; Van Grol, J.; Kern, T. CD40 mediates retinal inflammation and neuro-vascular degeneration. J. Immunol. 2008, 181, 8719-8726.

33. Abcouwer, S.F. Muller Cell-Microglia Cross Talk Drives Neuroinflammation in Diabetic Retinopathy. Diabetes 2017, 66, 261-263. [CrossRef] [PubMed]

34. Wang, J.; Xu, X.; Elliot, M.H.; Zhu, M.; Le, Y.-Z. Muller cell-derived VEGF is essential for diabetes-induced retinal inflammation and vascular leakage. Diabetes 2010, 59, 2297-2305. [CrossRef] [PubMed]

35. Yang, L.-P.; Sun, H.-L.; Wu, L.-M.; Guo, X.-J.; Dou, H.-L.; Tso, M.O.; Zhao, L.; Li, S.M. Baicalein reduces inflammatory process in a rodent model of diabetic retinopathy. Investig. Ophthalmol. Vis. Sci. 2009, 50, 2319-2327. [CrossRef] [PubMed] 
36. Monif, M.; Reid, C.A.; Powell, K.L.; Smart, M.L.; Williams, D.A. The P2X7 receptor drives microglial activation and proliferation: A trophic role for P2X7R pore. J. Neurosci. 2009, 29, 3781-3791. [CrossRef] [PubMed]

37. Klaus, G.G.; Choi, M.S.; Holman, M. Properties of mouse CD40. Ligation of CD40 activates B cells via a $\mathrm{Ca}(++)$-dependent, FK506-sensitive pathway. Eur. J. Immunol. 1994, 24, 3229-3232. [CrossRef] [PubMed]

38. Lazaar, A.L.; Amrani, Y.; Hsu, J.; Panettieri, R.A., Jr.; Fanslow, W.C.; Albelda, S.M.; Puré, E. CD40-mediated signal transduction in human airway smooth muscle. J. Immunol. 1998, 161, 3120-3127. [PubMed]

39. Du, Y.; Miller, C.M.; Kern, T.S. Hyperglycemia increases mitochondrial superoxide in retina and retinal cells. Free Radic. Biol. Med. 2003, 35, 1491-1499. [CrossRef] [PubMed]

40. Kowluru, R.A.; Odenbach, S. Effect of rlong-term administration of alpha-lipoic acid on retinal capillary cell death and the development of retinopathy in diabetic rats. Diabetes 2004, 53, 3233-3238. [CrossRef] [PubMed]

41. El-Remessy, A.B.; Al-Shabrawey, M.; Khalifa, Y.; Tsai, N.T.; Caldwell, R.B.; Liou, G.I. Neuroprotective and blood-retinal barrier-preserving effects of cannabidiol in experimental diabetes. Am. J. Pathol. 2006, 168, 235-244. [CrossRef] [PubMed]

42. Busik, J.V.; Mohr, S.; Grant, M.B. Hyperglycemia-induced reactive oxygen species toxicity to endothelial cells is dependent on paracrine mediators. Diabetes 2008, 57, 1952-1965. [CrossRef] [PubMed]

43. Behl, Y.; Krothapalli, P.; Desta, T.; DiPiazza, A.; Roy, S.; Graves, D.T. Diabetes-enhanced tumor necrosis factor-alpha production promotes apoptosis and the loss of retinal microvascular cells in type 1 and type 2 models of diabetic retinopathy. Am. J. Pathol. 2008, 172, 1411-1418. [CrossRef] [PubMed]

44. Joussen, A.M.; Doehmen, S.; Le, M.L.; Koizumi, K.; Radetzky, S.; Krohne, T.U.; Poulaki, V.; Semkova, I.; Kociok, N. TNF-a mediated apoptosis plays an important role in the development of early diabetic retinopathy and long-term histopathological alterations. Mol. Vis. 2009, 15, 1418-1428. [PubMed]

45. Vincent, J.A.; Mohr, S. Inhibition of caspase-1/interleukin-1b signaling prevents degeneration of retinal capillaries in diabetes and galactosemia. Diabetes 2007, 56, 224-230. [CrossRef] [PubMed]

46. Di Virgilio, F.; Chiozzi, P.; Falzoni, S.; Ferrari, D.; Sanz, J.M.; Enketaraman, V.; Baricordi, O.R. Cytolytic P2X purinoceptors. Cell Death Differ. 1998, 5, 191-199. [CrossRef] [PubMed]

47. Sugiyama, T. Enhancement of of P2X7-induced pore formation and apoptosis: An early effect of diabetes on the retinal microvasculature. Investig. Ophthalmol. Vis. Sci. 2004, 45, 1026-1032. [CrossRef] [PubMed]

48. Sugiyama, T. Role of P2X7 receptors in the development of diabetic retinopathy. World J. Diabetes 2014, 5, 141-145. [PubMed]

49. Solini, A.; Chiozzi, P.; Falzoni, S.; Morelli, A.; Fellin, R.; Di Virgilio, F. High glucose modulates P2X7 receptor-mediated function in human primary fibroblasts. Diabetologia 2000, 43, 1248-1256. [CrossRef] [PubMed]

50. Solini, A.; Chiozzi, P.; Morelli, A.; Adinolfi, E.; Rizzo, R.; Baricordi, O.R.; di Virgilio, F. Enhanced P2X7 activity in human fibroblasts from diabetic patients: A possible pathogenetic mechanism for vascular damage in diabetes. Arterioscler. Thromb. Vasc. Biol. 2004, 24, 1240-1245. [CrossRef] [PubMed]

51. Mukundan, L.; Bishop, G.A.; Head, K.Z.; Zhang, L.; Wahl, L.; Suttles, J. TNF receptor-associated factor 6 is an essential mediator of CD40-activated proinflammatory pathways in monocytes and macrophages. J. Immunol. 2005, 174, 1081-1090. [CrossRef] [PubMed]

52. Mackey, M.F.; Wang, Z.; Eichelberg, K.; Germain, R.N. Distinct contributions of different CD40 TRAF binding sites to CD154-induced dendritic cell maturation and IL-12 secretion. Eur. J. Immunol. 2003, 33, 779-789. [CrossRef] [PubMed]

53. Greene, J.A.; Portillo, J.-A.; Lopez Corcino, Y.; Subauste, C.S. CD40-TRAF signaling upregulates CXC3L1 and TNF-a in human aortic endothelial cells but not in retinal endothelial cells. PLoS ONE 2015, 10, e0144133. [CrossRef] [PubMed]

(C) 2017 by the author. Licensee MDPI, Basel, Switzerland. This article is an open access article distributed under the terms and conditions of the Creative Commons Attribution (CC BY) license (http:/ / creativecommons.org/licenses/by/4.0/). 